\title{
ANALYSIS OF GENETIC SIMILARITY OF LIMNOCHARIS FLAVA INDIVIDUALS GROWING AROUND A GOLD MINING AREA WITH ARSENIC CONTAMINATION
}

\author{
NEERATANAPHAN, L. ${ }^{1,2^{*}}-$ BOONMEE, S. $^{2}-$ SRISAMOOT, N. $^{3}-$ TANAMTONG, A. $^{4}-$ \\ TENGJAROENKUL, B. ${ }^{5}$ \\ ${ }^{1}$ Research Center for Environmental and Hazardous Substance Management, Khon Kaen \\ University, Khon Kaen 40002, Thailand \\ ${ }^{2}$ Department of Environmental Science, Faculty of Science, Khon Kaen University, \\ Khon Kaen 40002, Thailand \\ ${ }^{3}$ Division of Biotechnology, Faculty of Agro-Industrial Technology, Rajamangala University of \\ Technology Isan, Kalasin Campus, Kalasin 46000, Thailand \\ ${ }^{4}$ Department of Biology, Faculty of Science, Khon Kaen University, Khon Kaen \\ 40002, Thailand \\ ${ }^{5}$ Department of Veterinary Medicine, Faculty of Veterinary Medicine, Khon Kaen University, \\ Khon Kaen 40002, Thailand \\ *Corresponding author \\ e-mail: hlamya@kku.ac.th \\ (Received $12^{\text {th }}$ Nov 2015; accepted $11^{\text {th }}$ Apr 2016)
}

\begin{abstract}
This study aimed to determine the concentration of arsenic in the aquatic plant Limnocharis flava as well as this plant's genetic variability. Sediment and L. flava samples were collected from three studied sites at the edge of a stream near a gold mine. The arsenic concentrations in sediment and L. flava samples were analyzed using induction coupled plasma-mass spectrometry (ICP-MS). Genetic similarities (S) were studied using random amplified polymorphic DNA (RAPD) with dendrogram construction. The results showed that the arsenic concentrations in sediment and L. flava samples ranged from $4.595 \pm 0.318$ to $223.434 \pm 2.118$ and $0.081 \pm 0.020$ to $0.291 \pm 0.106 \mathrm{mg} / \mathrm{kg}$, respectively. To compare the samples studied to the reference site, RAPD fingerprints from 25 primers successfully produced 1,947 total bands used for dendrogram construction and $\mathrm{S}$ value analysis. The dendrogram construction separated L. flava into four clusters corresponding to their sampling sites. The $\mathrm{S}$ values of the studied sample sites compared to the reference site were $0.715-0.771,0.696-0.729$ and $0.757-0.836$ for sites 1,2 and 3 , respectively, whereas the values of the individual samples within each site were as high as 0.981 . Therefore, the genetic variation of this species is high and indicates that As is the one factor contributing to its genetic variations.
\end{abstract}

Keywords: sediment, stream, arsenic concentration, RAPD

\section{Introduction}

Gold mining activities have a considerable impact on the environment. Thailand has a gold mine located in the Wangsaphung district of the Loei province, resulting in affected human life. The gold mining industry has long encountered problems with heavy metals during gold extraction. Heavy metal pollutes the environment by separating and diffusing into soil and water (Henke, 2009). In addition to the local disturbance of the soil and aquatic ecosystems, a more widespread contamination of soils, vegetation and water sources by toxic concentrations of heavy metals can occur. 
The type of heavy metal contamination around gold mines mainly depends on the composition of the mined Au ore and the accompanying gangue. Several studies have been conducted to investigate the effects of heavy metals on some plant species. The effects of $\mathrm{Cd}, \mathrm{Cu}, \mathrm{Ni}$, and $\mathrm{Zn}$ on Medicago sativus (alfafa) (Peralta-Videa et al., 2002), and the toxicity of $\mathrm{Pb}$ and $\mathrm{Zn}$ on Avicennia marina (gray mangrove) (MacFarlance and Murchett, 2002) have previously been reported. Arsenic (As) is an environmental toxin that is found naturally in all soils (Cullen and Reimer, 1989; Smedley and Kinniburgh, 2002). As adversely affects biological activities as a teratogen, carcinogen or mutagen and has detrimental effects on the digestive system, respiratory system and immune system (Zhou and Huang, 2000; Zhou and Song, 2004; Liao et al., 2005). Due to the past and present use of As-based pesticides, mining operations, irrigation with Ascontaminated groundwater and fertilization with municipal solid wastes (Meharg et al., 2009), As has become part of the human solid food chain through contaminated crops and fodder. As contamination of the human food chain is a worldwide concern that is not restricted by economic boundaries. As is a heavy metal found in contaminated gold mining areas and can affect plant species (Boonmee et al., 2015). As is non-essential and generally toxic to plants. Roots are usually the first tissue to be exposed to As, where the metalloid inhibits root extension and proliferation. Upon translocation to the shoot, As can severely inhibit plant growth by slowing or arresting expansion and biomass accumulation, as well as compromising plant reproductive capacity through losses in fertility, yield and fruit production (Garg and Singla, 2011).

Aquatic plants are unique bioindicator species for the evaluation of water quality and subsequent risk assessment. Not only can we determine the bioavailability of contaminants, but also plant biomonitors allow for the detection of early signs of environmental disturbance before upper trophic levels are affected (Lafabrie et al., 2011). Aquatic plants have long been used for the evaluation and monitoring of metals in water (Cardwell et al., 2002). Higher plants produce varied responses to heavy metals in their environment that interfere with the genetic constitution of plants (De Wolf et al., 2004). Several plants, such as Allium cepa, Hordeum vulgare, Arabidopsis thaliana, Glycine max, Vicia faba and Zea mays, have been used as strong bioindicators of the genetic toxicity of environmental pollutants in recent years. Research on the effects of contaminant exposure on biological systems has historically focused on mechanisms of damage, and researchers have primarily studied test organisms exposed in laboratory settings (Anderson et al., 1994; Shugart and Theodorakis, 1994). Belfiore and Anderson (2001) have presented a summary of contemporary genetic assessment methods and a review of published studies of genetic effects in field-exposed aquatic organisms. Genetic techniques offer a powerful approach to assess contaminant-induced changes in populations. Direct tests of genetic adaptation are very effective in establishing a concrete and potentially deleterious population-level effect of contaminant exposure, but they are difficult to accomplish with most field-exposed organisms. Molecular genetic techniques have the potential to be very effective. As genotoxicity has been suggested because many plants are known to be injured by As contamination (Carbonell-Barrachina et al., 1997; Liu et al., 2005; Requejo and Tena, 2005), and some plant systems have been suggested as indicators of arsenic exposure (Steinkellner et al., 1998; Kovalchuk et al., 2001). Various molecular approaches, such as DNA fingerprinting based on inter-simple sequence repeat (ISSR) and random amplified polymorphic DNA (RAPD) methods, are generally used to effectively indicate genetic relationships. RAPD assays can be used to detect various types of genetic differentiation 
or DNA damage and mutations (point mutations, rearrangements and small deletions or insertions of DNA). This technique has been successfully applied to the study of heavy metals in plants and animals (De Wolf et al., 2004; Neeratanaphan et al., 2014; Boonmee et al., 2015). The development of this technology has provided a molecular marker for the detection of genetic alterations in response to heavy metal tolerance by looking directly at DNA sequence and structure, such as phylogenetic analyses using a highly conserved genetic marker (Héry et al., 2008).

Limnocharis flava is an aquatic plant species (family Limnocharitaceae) that is native to Central America and grows in wetlands. It is an important aquatic plant in the food chain ecosystem. L. flava is a noxious weed in irrigation channels in Indonesia and currently has invaded Sri Lanka and most of the Southeast Asian countries (Waterhouse, 2003). L. flava is a popular aquatic plant for consumption in a group of local Thai people. Knowledge of heavy metal accumulation and genetic similarity in plant species should clarify the bioindicator model of plants. This study aimed to determine the concentration of $A s$ in sediment and $L$. flava samples from the area around a specified gold mine. This study also explored the genetic similarity of Limnocharis flava growing around a gold mining area by RAPD with dendrogram construction and compared to a reference site, which was assumed to have no As contamination.

\section{Materials and methods}

\section{Sampling sites}

The three sampling sites utilized were located at the edge of a stream near the gold mine in the Wangsaphung district of the Loei province of Thailand (Fig. 1). The reference site was defined as the Pong River, where no gold mining activity occurs. Most of the land near the gold mine was engaged in farming and cropping plants such as rice, bananas, cassava, soybeans and rubber trees. Within the catchment area where the gold mine is situated, there are many small waterways (site 2) running from high elevation at the top of the plateau to lower areas. These waterways combine (sites 1 and 3) and eventually join the Loei River (Weerasiri et al., 2013).

\section{Sample collections}

L. flava and sediment samples were collected from three sampling sites at the edge of the stream near the gold mine (Fig. 1) and a reference site near the Pong River, which is located in a different province approximately $230 \mathrm{~km}$ from the studied sites. In each sampling site, L. flava samples were collected from three plants for As concentration analysis using an individual young $L$. flava leaf for DNA extraction. Three sediment samples were collected from the location of the plants and dried by air in a laboratory for analysis.

\section{Analysis of As concentration in L. flava and sediment samples}

A total of $2.5 \mathrm{~g}$ of each sample was predigested with $3 \mathrm{ml}$ of concentrated nitric acid overnight at $40^{\circ} \mathrm{C}$. After cooling, $2 \mathrm{ml}$ of $30 \%$ hydrogen peroxide was added. The container was covered, placed in a high-pressure stainless steel bomb and placed in an oven at $160^{\circ} \mathrm{C}$ for $4 \mathrm{~h}$. After cooling, each solution was diluted with Milli-Q water and transferred into a PET bottle for a total mass of $50 \mathrm{~g}$. The As concentration in each 
sample was determined using induction coupled plasma-mass spectrometry (ICP-MS; model 7500C) (Bailey et al., 2003). The wavelength analysis of ICP-MS for As was set to $75 \mathrm{~nm}$. The accuracy of the As concentration results was evaluated with certified reference material (CRM) via the 3111C method (APHA, 2005). Two aliquots of the CRM were spiked with a known amount of As spike standard. One spike was analyzed according to the $3111 \mathrm{C}$ method, and the other was analyzed with the $3111 \mathrm{~B}$ method (APHA, 2005). The As recoveries were in the 96-100\% range, which was determined to be acceptable (USEPA, 1994).

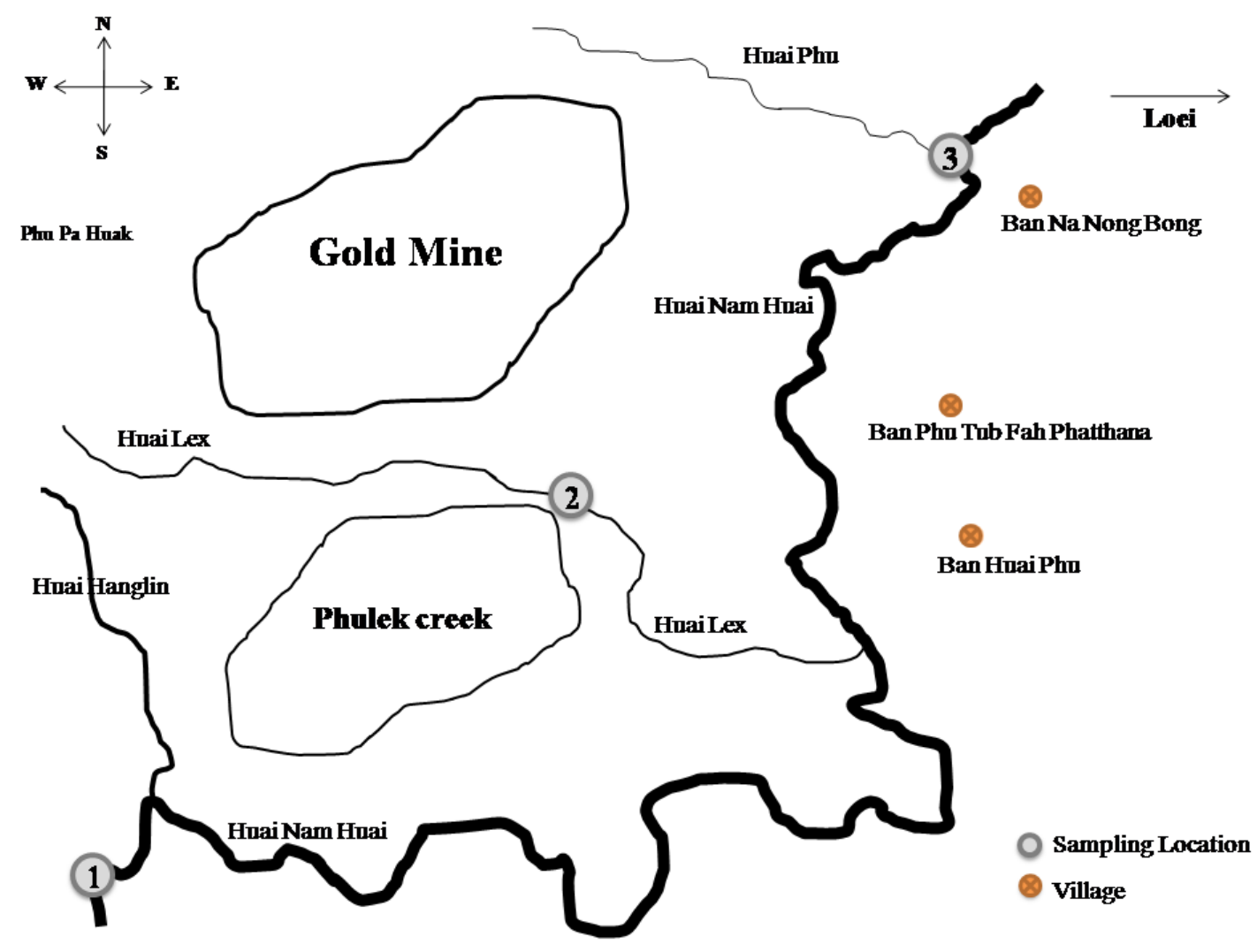

Figure 1. Overview of the gold mining area and locations of the three studied sites, indicated as sites 1 through 3

\section{DNA extraction}

Young leaves from individual L. flava plants at the three sampling sites and the reference site were collected and preserved in absolute ethyl alcohol for DNA extraction. The genomic DNA of plant samples was extracted using a Genomic DNA Extraction Kit (RBC Bioscience, Taiwan) following the manufacturer's instructions. The extracted DNA was checked by $0.8 \%$ agarose gel electrophoresis. DNA samples were diluted to a final concentration of $20 \mathrm{ng} / \mu \mathrm{l}$, and these dilutions were used as DNA templates in the PCR reactions. 


\section{DNA fingerprinting and analysis using RAPD markers}

DNA fingerprinting using RAPD markers was carried out on the L. flava samples in $25 \mu \mathrm{l}$ reactions consisting of GoTaq Green Master Mix (Promega), $0.5 \mu \mathrm{M}$ primer and 5 ng of DNA template. Ninety-six RAPD primers were screened; the 25 primers that successfully amplified clear bands are as follows (5' to $\left.3^{\prime}\right)$ : GGGTAACGCC, AGGTGACCGT, GTTGCGATCC, GTTTCGCTCC, TTTGCCCGGA, CCACAGCAGT, GTGAGGCGTC, GGGGGTCTTT, GATGACCGCC, GACGGATCAG, CACACTCCAG, GGACCCAACC, GAGAGCCAAC, TTATCGCCCC, CTGAGACGGA, GGTGGTCAAG, TCAGTCCGGG, AAGTCCGCTC, AGGCCCGATG, GTAGACGAGC, ACGACGTAGG, TGACCCCTCC, CAGGCGGCGT, AACGGGCAGC and CCGTCATTGG. The reaction mixture was incubated at $94^{\circ} \mathrm{C}$ for $3 \mathrm{~min}$, and the amplification was performed using the following thermal cycles: 35 cycles of denaturation for $1 \mathrm{~min}$ at $94^{\circ} \mathrm{C}$, annealing for $2 \mathrm{~min}$ at $40^{\circ} \mathrm{C}$, extension for $2 \mathrm{~min}$ at $72^{\circ} \mathrm{C}$ followed by a $7 \mathrm{~min}$ final extension at $72^{\circ} \mathrm{C}$ using a thermal cycler (Swift ${ }^{\mathrm{TM}}$ Maxi Thermal Cycler, Esco Micro Pte. Ltd.). The amplification products were detected using $1.2 \%$ agarose gel electrophoresis in TAE buffer and visualized using ethidium bromide. The resulting RAPD bands were used for the dendrogram construction.

The RAPD bands from all of the successful primers were discerned on an agarose gel and documented as the following diallelic characters: present $=1$ and absent $=0$. These resulting bands were used to construct a dendrogram using NTSYSpc 2.10p (Rohlf, 1998). The dendrogram and genetic similarities were produced and assessed.

\section{Results and Discussion}

\section{As concentrations in sediment and L. flava}

The As concentrations in the sediment and L. flava samples from the three studied sites and reference site are shown in Table 1. The average As concentration values in the sediment and L. flava samples at all sites ranged from $4.595 \pm 0.318$ to $223.434 \pm 2.118$ and $0.081 \pm 0.020$ to $0.291 \pm 0.106 \mathrm{mg} / \mathrm{kg}$, respectively. The As concentration in the sediment samples was higher than Thailand's soil quality standard level $(3.9 \mathrm{mg} / \mathrm{kg}$ ) (Pollution Control Department of Thailand, 2001), while the As concentration in the L. flava samples was lower than Thailand's food quality standard level $(2.0 \mathrm{mg} / \mathrm{kg})$ (Pollution Control Department of Thailand, 2001). The As concentrations in the sediment and L. flava samples at the reference site were lower than both of Thailand's standard control levels.

Table 1. Concentration of As in sediment and L. flava samples ( $\bar{X} \pm S D)$

\begin{tabular}{lccc}
\hline & Samples & Sediment $(\mathrm{mg} / \mathrm{kg})$ & L. flava $(\mathrm{mg} / \mathrm{kg})$ \\
\hline Site 1 & Individual 1 & 4.232 & 0.071 \\
& Individual 2 & 4.725 & 0.067 \\
& Individual 3 & 4.829 & 0.105 \\
\cline { 2 - 4 } & $\bar{X} \pm$ SD & $4.595 \pm 0.318$ & $0.081 \pm 0.020$ \\
\hline \multirow{2}{*}{ Site 2 } & Individual 1 & 231.671 & 0.370 \\
& Individual 2 & 227.809 & 0.333 \\
& Individual 3 & 210.823 & 0.170 \\
\cline { 2 - 4 } & $\bar{X} \pm$ SD & $223.434 \pm 2.118$ & $0.291 \pm 0.106$ \\
\hline
\end{tabular}




\begin{tabular}{llcc}
\hline Site 3 & Individual 1 & 18.199 & 0.119 \\
\cline { 2 - 4 } & Individual 2 & 16.610 & 0.131 \\
\cline { 2 - 4 } & Individual 3 & 17.543 & 0.129 \\
\cline { 2 - 4 } & $\bar{X} \pm$ SD & $17.450 \pm 0.798$ & $0.126 \pm 0.006$ \\
\hline Reference site & Individual 1 & 3.307 & 0.003 \\
\cline { 2 - 4 } & Individual 2 & 2.907 & 0.006 \\
\cline { 2 - 4 } & Individual 3 & 2.728 & 0.007 \\
\cline { 2 - 4 } & $\bar{X} \pm$ SD & $2.980 \pm 0.296$ & $0.005 \pm 0.002$ \\
\hline Thailand standard & & 3.9 & 2.0 \\
\hline
\end{tabular}

This research revealed that the As concentration in sediment and the three studied plant samples correlates with genetic similarity. In addition, the Groundwater Research Center of Thailand (2010) has reported that the highest As contamination in water near the gold mine areas is $300 \mathrm{mg} / \mathrm{l}$. The mean concentration of As in the sediment from the different sites shows values decreasing in the sequence of site $2>$ site $3>$ site 1 . The highest As concentration in the sediment from site 2 could be due to soil erosion and water runoff from the rainy season. Alternatively, this site is nearest to the gold mine, which means that As contamination could also be caused by gold mining activities. The lower areas combine into one stream before finally joining the Loei River (Fig. 1). Study site 2 has a small stream near the gold mine and a lower flow rate than sites 1 and 3. Thus, the As concentration in the sediment of site 2 is higher than those of sites 3 and 1. The stream runoff from site 1 to 3 and As contamination was deposited into the sediment at site 3. The As concentration in sediment was higher than that of the plant samples at all sites. Fortunately, the As concentration of L. flava is lower than the standard level of Thailand. The sampling sites have running water leaching As from the gold mine into sites 1 and 3, which is then deposited into the sediments and accumulates in L. flava. This process likely accounts for the increased As concentration during the rainy season. As this study is a field investigation, there are other possible environmental measures of toxicity in addition to As contamination.

\section{DNA fingerprinting of L. flava}

The 25 successful RAPD primers mentioned generated clear and invaluable fingerprinting profiles; example RAPD profiles are shown in Figure 2. The RAPD patterns produced 1,947 total bands ranging in size from $100 \mathrm{bp}$ to $2,500 \mathrm{bp}$; these bands were used for dendrogram construction. The dendrogram distinguished the studied samples into four groups based on their sites of study. The first group comprised the individuals $(1,2$, and 3$)$ of the reference site, the second group comprised the individuals $(1,2$, and 3$)$ of site 1 , the third group comprised the individuals $(1,2$, and 3$)$ of site 2 , and the fourth group comprised the individuals (1, 2, and 3 ) of site 3 (Fig. 3). The pairwise genetic relationships in terms of similarity $(S)$ for all of the studied samples are shown in Table 2. The $\mathrm{S}$ values among the individual samples of each site ranged from $0.921-0.981,0.921-0.963,0.902-0.958$, and $0.893-0.935$ for the reference site, site 1 , site 2 and site 3, respectively. The $S$ values of the samples from each site compared to the reference site were $0.715-0.771,0.696-0.729$ and $0.757-0.836$ for sites 1, 2 and 3, respectively. The average As concentration values in the L. flava samples at sites 1,2 and 3 in addition to the reference site were $0.081 \pm 0.020,0.291 \pm 0.106$, 
$0.126 \pm 0.006$ and $0.005 \pm 0.002 \mathrm{mg} / \mathrm{kg}$, respectively. The aquatic plant $L$. flava and the As concentration of each studied site demonstrated a correlation according to the grouping $\mathrm{S}$. The $\mathrm{S}$ values of the samples from site 2 compared to the reference site were lower than those of the other sites. The As concentration in L. flava samples at site 2 affected the genetic material compared to the reference site. The As concentration in the plant samples at site 2 was higher than those at sites 3 and 1; the lowest $S$ value of an individual studied sample was lower than for samples at sites 1 and 3 . These data indicated that the L. flava in the area near the gold mine adapted to their environment. Thus, plants growing in As-contaminated sites need to develop some degree of tolerance to As toxicity to survive. The aquatic plant L. flava in this area is affected by the gold mine but can still be of good quality. This aquatic plant can endure As contamination and survive in the environment near the gold mine, which is a highly contaminated area. Additionally, this species has very high genetic diversity, which is demonstrated by the low $S$ value of the species. Normally, the $S$ value of a species should be $85-100 \%$, but L. flava has a wider range of S values (0.692-0.981), indicating genetic diversity. Therefore, the $S$ value indicates that it endures a varied environment, including one with high As contamination.

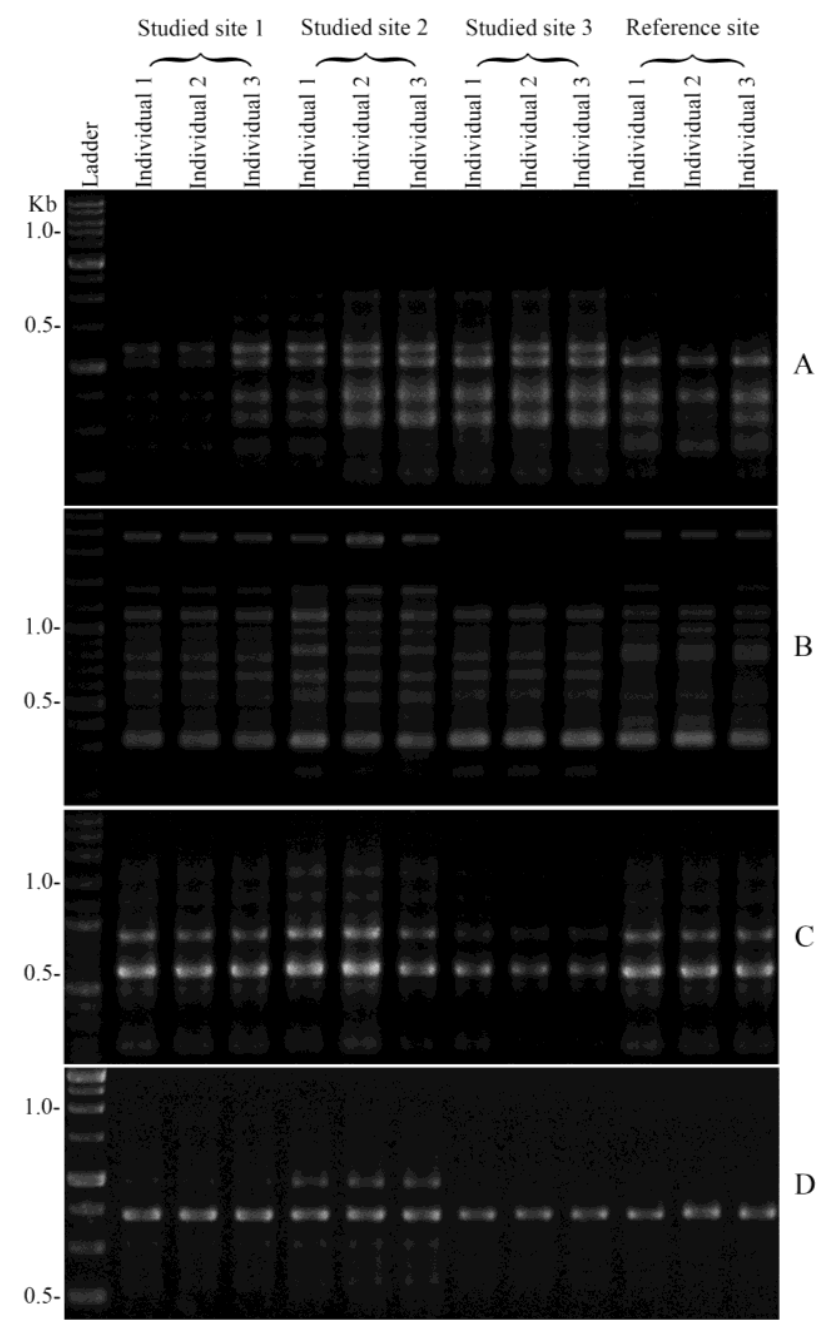

Figure 2. Examples of RAPD fingerprints from L. flava samples in the studied sites and reference site generated using the primers GTTGCGATCC (A), CACACT CCAG $(B)$,

CTGAGACGGA $(C)$ and AGGCCCGATG $(D)$ 


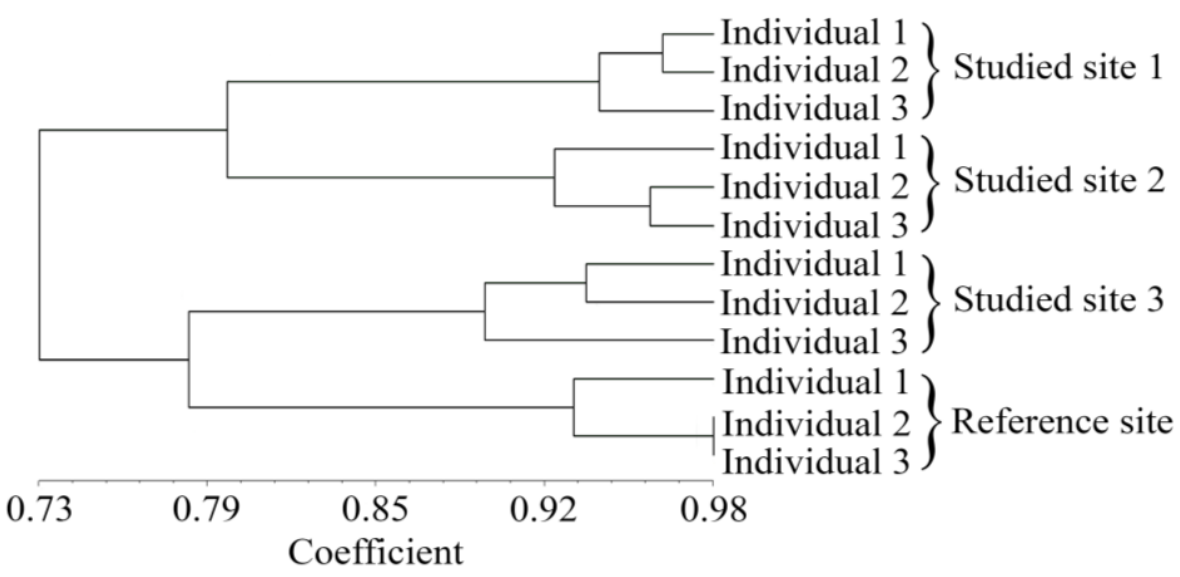

Figure 3. The dendrogram constructed using 25 RAPD primers and the NTSYSpc $2.10 p$ program, showing the genetic relationships among the individual samples at the three studied sites and the reference site

Table 2. Relationships between all pairwise individual studied samples at the three studied sites and reference site, indicating genetic similarity values

\begin{tabular}{|c|c|c|c|c|c|c|c|c|c|c|c|c|c|}
\hline & \multicolumn{3}{|c|}{$\overbrace{}^{\text {Studied site } 1}$} & \multicolumn{3}{|c|}{$\overbrace{}^{\text {Studied site } 2}$} & \multicolumn{3}{|c|}{$\overbrace{}^{\text {Studied site } 3}$} & \multicolumn{3}{|c|}{ Reference site } \\
\hline & & 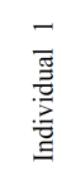 & 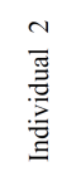 & 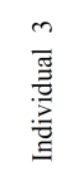 & 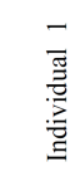 & 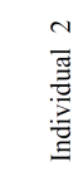 & 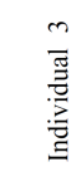 & 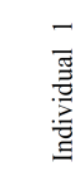 & 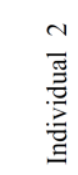 & 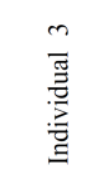 & 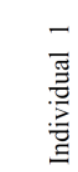 & 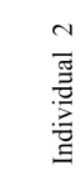 & 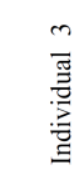 \\
\hline \multirow{3}{*}{ Studied site 1} & Individual 1 & 1.000 & & & & & & & & & & & \\
\hline & $\{$ Individual 2 & 0.963 & 1.000 & & & & & & & & & & \\
\hline & Individual 3 & 0.921 & 0.958 & 1.000 & & & & & & & & & \\
\hline \multirow{3}{*}{ Studied site 2} & Individual 1 & 0.780 & 0.818 & 0.860 & 1.000 & & & & & & & & \\
\hline & Individual 2 & 0.762 & 0.799 & 0.841 & 0.944 & 1.000 & & & & & & & \\
\hline & Individual 3 & 0.748 & 0.785 & 0.827 & 0.902 & 0.958 & 1.000 & & & & & & \\
\hline \multirow{3}{*}{ Studied site 3} & Individual 1 & 0.757 & 0.757 & 0.752 & 0.724 & 0.752 & 0.776 & 1.000 & & & & & \\
\hline & Individual 2 & 0.729 & 0.738 & 0.762 & 0.724 & 0.752 & 0.776 & 0.935 & 1.000 & & & & \\
\hline & Individual 3 & 0.724 & 0.724 & 0.729 & 0.692 & 0.701 & 0.724 & 0.902 & 0.893 & 1.000 & & & \\
\hline \multirow{3}{*}{ Reference site } & Individual 1 & 0.771 & 0.752 & 0.738 & 0.729 & 0.720 & 0.724 & 0.790 & 0.771 & 0.794 & 1.000 & & \\
\hline & Individual 2 & 0.748 & 0.738 & 0.724 & 0.715 & 0.706 & 0.720 & 0.766 & 0.766 & 0.827 & 0.921 & 1.000 & \\
\hline & Individual 3 & 0.748 & 0.738 & 0.715 & 0.706 & 0.696 & 0.710 & 0.785 & 0.757 & 0.836 & 0.939 & 0.981 & 1.000 \\
\hline
\end{tabular}

\section{Conclusions}

Sediment and L. flava samples were taken from three sites near a gold mining area for analysis of As contamination. The concentration of As in L. flava did not exceed the standard level of contamination in food as determined by the Pollution Control Department of Thailand. Unfortunately, the concentration of As in the sediment was higher than the standard level. Although the As concentration in L. flava is low, it may still have an effect on the extent of genetic similarity of the plant based on RAPD marker analysis. In addition, this study suggests that RAPD assays are very useful tools for ecotoxicology and are useful biomarker assays for the detection of the genotoxic effects of As on plants. Lastly, the accumulation of As in aquatic plant species should be of concern, not only because As potentially affects aquatic organisms but also because it potentially affects human health. The accumulation of As in other aquatic 
plants, especially edible plants, should be studied. The public should be informed of the results of this research so that they can properly consider the consumption of aquatic plants grown in contaminated areas.

Acknowledgments. This research was supported by Khon Kaen University under the Incubation Researcher Project and the Research Center for Environmental and Hazardous Substance Management. We also wish to thank the Molecular Systematics Laboratory at the Department of Biology, Faculty of Science, Khon Kaen University for DNA analysis. We are deeply grateful to Professor Dr. Arunrat Chaveerach for her helpful recommendation of our work.

\section{REFERENCES}

[1] Anderson, S., Sadinski, W., Shugart, L., Brussard, P., Depledge, M., Ford, T., Hose, J., Stegeman, J., Suk, W., Wirgin, I., Wogan, G. (1994): Genetic and molecular ecotoxicology: a research framework. - Environ. Health. Perspec. 102: 3-8.

[2] APHA. (2005): Standard methods for the examination of water and wastewater. American Public Health Association, 21 st edition, Washington DC. 2001-3710.

[3] Bailey, R.M., Stokes, S., Bray, H. (2003): Inductively coupled plasma mass spectrometry (ICPMS) for dose rate determination: some guidelines for sample preparation and analysis. - Oxford, UK:Oxford Luminescence Research Group, School of Geography and the Environment, University of Oxford.

[4] Belfiore, N.M., Anderson, S.L. (2001): Effects of contaminants on genetic patterns in aquatic organisms: a review. - Mutat. Res. 489: 97-122.

[5] Boonmee, S., Neeratanaphan, L., Tanee, T., Khamon, P. (2015): The genetic differentiation of Colocasia esculenta growing in gold mining areas with arsenic contamination. - Environ. Monit. Assess. 187(5): 227-234.

[6] Carbonell-Barrachina, A.A., Burló, F., Burgos-Hernández, A., López, E., Mataix, J. (1997): The influence of arsenite concentration on arsenic accumulation in tomato and bean plants. - Sci. Hortic. 71: 167-76.

[7] Cardwell, A., Hawker, D., Greenway, M. (2002): Metal accumulation in aquatic macrophytes from Southeast Queensland, Australia. - Chemosphere. 48: 653-663.

[8] Cullen, W.R., Reimer, K.J. (1989): Arsenic speciation in the environment. - Chem. Rev. 89: 713-764.

[9] De Wolf, H., Blust, R., Backeljiau, T. (2004): The use of RAPD in ecotoxicology: A review. - Mutat. Res. 566: 249-262.

[10] Garg, N., Singla, P. (2011): Arsenic toxicity in crop plants: physiological effects and tolerance mechanisms. - Environ. Chem. Lett. 9: 303-321.

[11] Groundwater Research Center of Thailand. (2010): Performance report of prevention in environmental impact and environmental monitoring of gold mining project (Phu Thap Pha, Loei province). - Performance Report, Faculty of Technology, Khon Kaen University, Khon Kaen, Thailand.

[12] Henke, K.R. (2009): As environmental chemistry health threats and waste treatment. - 1st ed., John Wiley and Sons. Ltd., Kentucky.

[13] Héry, M., Gault, A.G., Rowland, H.A., Lear, G., Polya, D.A., Lloyd, J.R. (2008): Molecular and cultivation dependent analysis of metal-reducing bacteria implicated in arsenic mobilization in south-east asian aquifers. - Appl. Geochem. 23: 3215-3223.

[14] Kovalchuk, O., Titov, V., Hohn, B., Kovalchuk, I. (2001): A sensitive transgenic plant system to detect toxic inorganic compounds in the environment. - Nat. Biotechnol. 19: 568-72. 
[15] Lafabrie, C., Major, K.M., Major, C.S., Cebrián, J. (2011): Arsenic and mercury bioaccumulation in the aquatic plant, Vallisneria neotropicalis. - Chemosphere. 82: 1393-1400.

[16] Liao, X.Y., Chen, T.B., Xie, H., Liu, Y.R. (2005): Soil As contamination and its risk assessment in areas near the industrial districts of Chenzhou City, southern China. Environ. Int. 31: 791-798.

[17] Liu, X., Zhang, S., Shan, X., Zhu, Y.G. (2005): Toxicity of arsenate and arsenite on germination, seedling growth and amylolytic activity of wheat. - Chemosphere. 61: 293301.

[18] MacFarlance, G.R., Murchett, M.D. (2002): Toxicity, growth and accumulation relationships of copper, lead and zinc in the grey mangrove Avicennia marina (Forsk.) Vierch. - Mar. Environ. Res. 54: 65-84.

[19] Meharg, A.A., Williams, P.N., Adomako, A., Lawgali, Y.Y., Deacon, C., Villada, A., Cambell, R.C.J., Sun, G., Zhu, Y.G., Feldmann, J., Rabb, A., Zhao, F.J., Islam, R., Hossain, S., Yanai, J. (2009): Geographical variation in total and inorganic arsenic content of polished (white) rice. - Environ. Sci. Technol. 43: 1612-1617.

[20] Neeratanaphan L., Sudmoon, R., Chaveerach, A. (2014): Genetic erosion in freshwater snail, Filopaludina martensi affected by lead and cadmium. - Appl. Ecol. Env. Res. 12(4): 991-1001.

[21] Peralta-Videa, J.R., Gardea-Torresdey, J.L., Gomez, E., Tiermann, K.J., Parsons, J.G., Carrillo, G. (2002): Effect of mixed cadmium, copper, nickel and zinc at different pHs upon alfafa growth and heavy metal uptake. - Environ. Pollut. 119: 291-301.

[22] Pollution Control Department of Thailand. (2001): Water quality standards. http://www.pcd.go.th/. Accessed 10 Aug 2012.

[23] Requejo, R., Tena, M. (2005): Proteome analysis of maize roots reveals that oxidative stress is a main contributing factor to plant arsenic toxicity. - Phytochemisty. 66: 151928.

[24] Rohlf, F. J. (1998): NTSYS_pc: Numerical taxonomy and multivariate analysis system, version 2.1. - Applied Biostatistics, New York.

[25] Shugart, L., Theodorakis, C. (1994): Environmental genotoxicity: probing the underlying mechanisms. - Environ. Health. Perspect. 102: 13-17.

[26] Smedley, P.L., Kinniburgh, D.G. (2002): A review of the source, behaviour and distribution of arsenic in natural waters. - Appl. Geochem. 17: 517-568.

[27] Steinkellner, H., Mun-Sik, K., Helma, C., Ecker, S., Ma, T.H., Horak, O. (1998): Genotoxic effects of heavy metals: comparative investigation with plant bioassays. Environ. Mol. Mutagen. 31: 183-91.

[28] U.S. Environmental Protection Agency. (1994): Sample preparation procedure for spectrochemical determination of total recoverable element, method 200.2. Environmental Monitoring Systems Lab, Cincinnati, Ohio.

[29] Waterhouse, B.M. (2003): Know your enemy: records of potentially serious weeds in northern Australia, Papua New Guinea and Papua (Indonesia). - Telo-pea. 10: 477-84.

[30] Weerasiri, T., Wirojanagud, W., Srisatit, T. (2013): Localized profile of As in sediment and water in the area around gold mine. - Curr. World. Environ. 8: 231-240.

[31] Zhou, Q.X., Huang, G.H. (2000): Environmental biogeochemistry and global environmental changes. - Science Press, Beijing, China.

[32] Zhou, Q.X., Song, Y.F. (2004): Principles and methods of contaminated soil remediation. - Science Press, Beijing, China. 